\title{
Effect of Library Automation on Performance of Librarians in Private Universities in South-West Nigeria
}

\author{
Dolapo Peter Olagoke \\ Joseph Ayo Babalola University Library, Ikeji-Arakeji, Osun State, Nigeria \\ Joseph Adeniyi Kolawole \\ Joseph Ayo Babalola University Library, Ikeji-Arakeji, Osun State, Nigeria
}

\begin{abstract}
This study focuses on effect of library automation on the performance of librarians in South-West, Nigeria. The survey research design was used. The population of the study was 349 librarians from 22 private university libraries in South-West Nigeria. 272 copies of the questionnaire were returned giving a return rate of $80.1 \%$. Data collected were analyzed using descriptive statistics and Pearson's Product Moment Correlation Coefficient. Findings revealed that out of the six library services identified in this study, five were fully automated and $90 \%$ of the private university libraries have automated their services. From the findings, librarians' performance had been increased by $70 \%$ as a result of automated library in private universities in South West Nigeria. The study showed that there was significant and positive relationship between library automation and librarians' performance in private university libraries $(\mathrm{r}=.372, \mathrm{p}<.01)$.

This study concluded that most private university libraries in South-West Nigeria were fully automated which allowed librarians to increase the quality of services rendered. Library service automation contribute greatly to librarians performance in private universities in South-West Nigeria. This study recommended that university library managers need to further enlighten both the library staff and library users on the importance of library automation by organizing workshops, seminars and conferences in order to meet the current information needs of users.
\end{abstract}

Keywords: Library automation, Librarians, Librarians' performance and Private universities

DOI: $10.7176 / \mathrm{IKM} / 9-5-01$

Publication date:May $31^{\text {st }} 2019$

\section{Introduction}

Academic libraries are institutions that are established to take care of the information need of students, lecturers, researchers and other community of scholars. Their mission is to offer quality information services and knowledge products (print and electronic) to community of scholars. According to Uddin (2009), academic libraries are cost effective information and knowledge resource centres that serve a community of scholars.

Libraries carry out different actions such as indexing and abstracting, current awareness services, Selective Dissemination of Information (SDI) and answering of user's queries to ensure that users of the library are satisfied. As the library carries out these functions through information management professionals, the availability of these library resources does not guarantee their access and use by the university community. The university library managers are expected to stimulate, enhance, and sustain the interest of users in visiting the library and using the information contained therein. The knowledge of how to access and use information in the library so as to improve their work can lead to effective librarians' performance in any university system. Library is saddled with much responsibilities which include analysis of patron request to determine needed information and assist in locating that information, search standard reference materials including online resources and internet in order to answer patrons' reference questions, to teach library patrons how to search for information using databases, to keep records of circulation and materials and catalogues in order to select and order print of electronic resources.

Librarian's performance is considered to be the fulfillment of an obligation, in a way that releases the performer from all responsibilities under the organization. Yaya (2007) defined librarian performance as the work (activities) carried out by the worker towards the achievement of their organizational goals. It is an act of fulfilling one's obligation to the organization within one's ability and proficiency. This depends not only on the amount of physical effort exerted but also on the person's mental ability to perform work in the library. According to Borman and Motowidlo (2012), librarians' performance can be measured in two ways: task performance and contextual performance. Task performance is described as behaviours that directly or indirectly subsidize to the organization's main work and contextual performance as behaviours that backing the organizational, social and psychological situation in which the organization main work must function and measurable.

Performance measurement is a means of defining the performance of an individual, group or organization. Task performance events usually vary from one organization to another which is called job related behaviour, 
but contextual performance events are common to work. Task performance procedures include quality of work done, quantity of work performed, cost effectiveness and job relevant behaviours while the contextual measures consist of following organizational rules and procedure, assisting and cooperating with co-workers, volunteering for additional work and other personal behaviours. Some of the tasks performed in the library include the registration of library users, classification and cataloguing of library materials, charging and discharging of books and attending to users' needs. Library work includes cataloguing and classification of materials, provision of reference services, charging and discharging of materials to users. The focus of this study is on the task performance measurements.

Librarians performance can be assessed by several methods among which include motivation (the desire to do the job), ability (capacity to do the job) and the work environment, the tools, materials and information needed to do the job. If libraries lack the ability, tools and material to perform the job it will have negative effect on librarian performance. Librarians' performance is the ability to carry out statutory functions which are based on the library's units and development as well as library objectives. Oyintola, Abiodun and Ajani (2013), define Librarians" performance as "that aspect of work behaviour that is of relevance to the librarian performance and success". Librarian performance is geared towards meeting, not only the users' information needs, but is also a basis for promoting staff in the library. Librarian performance in this period has witnessed positive changes by automation process.

Librarian now provide information services to users in a new and better means with the aid of library automation and electronic resources. They also offer personal help to users who utilize the resources at the library. Another routine area where libraries use automation and electronic resources is in the area of interlibrary loan where service delivery is carried out through electronic network whereby resources can be shared among many users within Local Area Network (LAN) or Wide Area Network (WAN). Apart from interlibrary loan, we also have Online Public Access Catalogue (OPAC) which offers users the opportunity to access the library collections without the usage of catalogue boxes. This OPAC, according to Alabi and Inuwa (2010) is the library database where library users can have access to the resources of the library through online computer terminals in the library. This shows that there is no area of library work that libraries have not been able to apply the library automation in their daily operation to aid their performance.

One of the main functions of the library is to help people find information; organize it, retrieve and maintain the system which allows access to fit or teach people how to use the information in our surroundings. Library automation ensure cost effectiveness when purchasing library materials, the library will know the materials that are of high use and most requested by users. The level of library automation is very important as this will enable the librarians to have prompt attention to users' needs and improved their performance.

\subsection{Statement of the Problem}

Library automation is essential for today's library operations and services. However, the ability of librarians to perform their job effectively and efficiently is influenced by their capacity to use automated library. Librarians' performance appears not to meet up with the current level of users' demand for information and the rate at which the users want to get information. Currently, some libraries in South-West, Nigeria may not have sufficient skills and competence on the use of library automation. Lack of library automation has adverse effect on the quality of service delivery of the library which affects their performance also. This is the reason why this study investigated the effect of library automation on performance of Librarians in private universities in South-West, Nigeria.

\subsection{Objective of the Study}

The main objective of this study is to investigate the effect of library automation on librarians' performance in private universities in South-West, Nigeria. The specific objectives are to:

1. identify the level of library automation in private universities in South-West, Nigeria;

2. determine the librarians' performance in private university libraries in South-West, Nigeria;

3. determine the influence of library automation on librarians' performance in private Universities in SouthWest, Nigeria;

4. identify the challenges of library automation in private universities in South-West, Nigeria.

\subsection{Research Questions}

To achieve the foregoing objectives, the following research questions were posed:

1. What is the level of library automation in private universities in South-West, Nigeria?

2. What are the perceive effect of library automation on librarians' performance of private university libraries in South -West, Nigeria?

3. What are the challenges of library automation in private universities in South-West, Nigeria? 


\subsection{Hypotheses}

This study is guided by the following hypotheses and were tested at $5 \%$ level of significance.

$\mathrm{H}_{01}$ : There is no significant relationship between library automation and performance of librarians in private universities in South-West, Nigeria.

\subsection{Scope of the Study}

The study covered the six states in South-West, Nigeria, which are Ekiti, Lagos, Ogun, Ondo, Osun, and Oyo. The study involved librarians in 22 private universities libraries in the South-West, Nigeria who were established from year 1999 to 2014. Public universities are thus excluded. The study focuses on library services which include acquisition, cataloguing, circulation, reference and serials sections of the library. The study concentrates on the task performance of librarians in their daily job which includes quality of work done, quantity of work performed, communication skills, decision making, timeless and ability to attend promptly to request from library patrons, and relationship with coworkers The study considers the private universities libraries that have automated their library and electronic resources.

\subsection{Significance of the Study}

Library automation is used to promote quality of service, level of operation, library user satisfaction and increase productivity of library. Library automation in the library would serve as motivating tools for the library in discharging their duties in an effective and efficient way. The findings of this study would help library and the policy makers who are involved in the operation of library services and enhance research work. The study will enable librarians and university management on accountability of fund given to the library and monitoring how the library fund is spent over a year. Lastly, the study would contribute to the body of knowledge while serving as a useful source of information for future research regarding this subject matter.

\subsection{Review of Literature}

\subsection{Library Automation}

Library automation is the process of automating in house functions such as circulation, cataloguing, acquisition, serial controls etc. Automation means the application of machines to perform the different routines, repetitive and clerical jobs involved in functions and services of the libraries. Library automation may be defined as the application of automatic data processing computers to perform traditional library house-keeping activities such as acquisition, circulation, cataloguing, reference and serials control. Today Library Automation is by far the most commonly used terms to describe the mechanization of library activities using the computer (Uddin, 2009). Library automation can also be described as the application of computers and utilization of computer based products and services in the performance of different library operations and functions in the provision of various services and production of output products. There is a great impact of computers and information technology and its application on the library due to a process of great change taking place in libraries. Modern technology is tending to alter radically the nature of our society and affect the prevailing economic, political and social values and libraries are also in the process. Industrialized countries were the first to realize that in the context of stock of knowledge, classical approaches relating to storage, retrieval and utilization of the information were no longer adequate and effective and that the solution lay in making fullest use of new developments in electronics, computer, telecommunications and micro-recording.

Library automation implies a high degree of mechanization of various routine and repetitive tasks usually performed by human beings. With the advent of automation, the human intervention is reduced to a great extent. The appearance of computer has greatly increased library automation. In addition to computer advancement, telecommunication and audio-visual technologies gave way to new possibilities in information handling; the use of computers is on the increase even in some specialized libraries in developed countries. Library automation includes use of computers and other semi-automatic devices like punched cards to reprography. These are semiautomatic because human intervention is greater in extent. Library automation is principally the use of computers, associated peripheral media (magnetic tapes, disks, optical media, etc), computer based products and services in library work.

Library automation makes work easier in the library. The following are some of its reasons;

1. Avoid retyping if we want to include or delete any matter, thus saving time and energy.

2. Retrieve much more precise and accurate information in less time as compared to manual search.

3. Get printed list of a specific subject within a few minutes.

4. Heavy bulk of data can be stored in the computer and thus certain problems, which arise with storing records in wooden cabinet, are avoided (Hussain \& Raza, 2002).

Due to these advantages of a computer, computer became a universally accepted tool to provide assistance to man in all fields. In the field of Library Science, the need for making use of computers i.e. library automation was felt due to the following reasons: 
Traditional methods for handling information are inadequate. This age is termed as the 'information age' because large amount of information is being generated every moment. This information which is generated is stored and retrieved in a library which is used by the patrons. In the libraries, there are various methods of handling information like providing reference service, cataloguing etc. Due to increase in research activities, and interdisciplinary specialization in different fields as a result of information explosion, it becomes necessary for libraries and information centers to update their information base. Hence library automation is necessary. There is need for co-operation and resource sharing as no library in this world is self-sufficient and therefore to satisfy its users' demands, the concept of resource sharing comes into existence. In resource sharing the resources of one library are lent to another library for a stipulated period of time. So, library automation helps to promote resource sharing by saving a lot of time and effort of library staff as well as the users (Fatoki, 2002).

\subsection{Barriers to Library Automation and Some Library Automation Software}

Library automation brings great changes in the functioning of the library ensuring effective and efficient library services. In spite of these great advantages there are many barriers which occur at the time of implementing the automation in libraries. Raiz (2008) has given the following as barriers faced by the library during automation. Fear of adverse impact on employment, apprehension that the technology could be too expensive, the library staff has to undergo extensive training, lack of support from the management, may be owing to budget constraints, retrospective conversion of data. Some Library Automation software are; Alice for Windows, Automated Library (AUTOLIB). The Information Navigator Library Software (TINLIB), Graphic Library Automation System (GLAS), Web-Based Integrated Library System (WEBLIS), Koha, Automation of Libraries and Centres of Documentation (ABCD), Evergreen Software, Integrated Library Management System, Newgenlib, Computer Documentation System/ Integrated Set of Information Systems (CDS/ISIS)

\subsection{Advantages of Library Automation}

Many activities of a library are routine in nature; a few are repetitive. Automation of these activities helps in managing the library's resources in a better way at the same time saving time, money and manpower. For example, once the bibliographic details like author, title, edition, publisher, price, ISBN number, etc are entered at the time of ordering, the same data can be used for accessioning, cataloguing (OPAC), and circulation. Other important factors associated with automation are speed, and accuracy. One can imagine the time saved in literature searches and in preparing bibliographies. Automation also offers freedom from doing repetitive and routine work as well as enables providing services promptly and more efficiently, cutting down on time and improving productivity. Automation facilitates generation of a number of reports for better decision making in the effective management of the library. Availability of various statistical and other usage reports and performance reports will ensure better appreciation from library users. For example, vendor performance analysis is possible. Subject-wise or project department-wise budget can be monitored. Circulation data can provide information on titles that are in great demand so that more copies can be procured if needed. Many current awareness services like current additions, contents of books and journals, etc can be provided to users (Moorthy, 2004)

\subsection{Automation of Library and Librarians' Performance}

According to Aswal (2006), library automation is pivotal to librarian effectiveness because it increases staff productivity, enhances housekeeping operations, enables advancement in technology and easy access to external information through the Internet. Sudhamani (2010), supporting the above enumerated the following as the relevance of library automation. It improves the quality, speed and effectiveness of service; improves access to remote users; facilitates wider dissemination of information products and services, facilitates resource sharing among librarians, enables rapid communication with other librarians, improves the management of physical and financial resources and facilitates generation of reports for better decision making and effective management of the library. It is in line with the above that Neelakandan, Duraisekar, Balasubramani, and Ragavan (2010) also stated that for expeditious retrieval and dissemination of information and better services to the clientele, application of modern techniques in the form of automation has become absolutely indispensable. An automated library will help its users with quick, accurate, and prompt services. Automating the information available in the library benefits both the staff and users alike.

Generally, Automation of library is relevant as a result of the following:

a. Improves access: Automated libraries enable faster, more efficient and more comprehensive searches. It retrieves and sorts materials using the varying access points such as: the title, author, International Standard Book Number (ISBN), keywords, publisher and publication date by mere simple mouse clicks. Posting the electronic catalogue on the Internet also enables easy access to the library holdings.

b. Improves the quality and effectiveness of services to remote users: Automation improves library services in line with new forms of learning, such as e-learning and distance education. It enables libraries to satisfy the 
demand for ready reference/information services.

c. Saves professional manpower time: Professional staff time that could have been spent in performing routine and repetitive technical works such as bibliographic verification/search, order placement, checking duplicates, charging and discharging of records as well as cataloguing jobs are saved in an automated library environment.

d. Facilitates wider dissemination of information products and services: It gives room for users even from remote areas to access the library resources and also enables easy and timely provision of such services as Current Awareness (CA) and Selective Dissemination of Information (SDI).

e. Resource-sharing among libraries (Union Catalogues): Automated cataloguing standards, such as MARC (Machine Readable Cataloging), allow for quicker cataloguing of library items and also makes the sharing of materials among libraries much easier and much more affordable. It enables consortium formulation and makes library collaboration very easy.

f. Control and management: Automation enables library staff to circulate materials with ease, accurately track individual users' transactions, and enables users to do self-charging and discharging.

Librarians have realized that in the context of stock of knowledge, classical approaches relating to storage, retrieval and utilization of the information are no longer adequate and effective and that the solution lay in making fullest use of new developments in electronics, computer, telecommunications and micro-recording. With the advent of automation, the physical activities of the library are reduced to a great extent. In addition, computer advancement, telecommunication and audio-visual technologies have given way to new possibilities in information handling.

The goal of the library is to satisfy the users' demand. The user of the library will be satisfied only if the library acquires reading materials based on the users' demands which results in effective and efficient collection development of the library hence, acquisition of reading materials is an important job and is also highly labour intensive. Therefore, automation in this area is very much required. Satyanarayana (2003) has given the major objectives of an automated acquisition system as elimination of maintenance of several manual files which consumes a lot of the staff's time. It eliminates many errors in reporting and control. It improves accuracy in all facets of the acquisition process. It creates accurate and timely financial data recording, accounting and reporting, improved ability to track orders, receipts, invoice and claims, integration of acquisition with cataloguing and serial control for more effective bibliographic holdings, provide necessary management information reports and improved services to the users through faster, timelier processing of orders and receipts.

OPAC (Online Public Access Catalogue) is one of the existing aspects of library automation. OPAC is a catalogue, which is available for online searching. Such OPAC may be searched from a terminal within the library or at a terminal elsewhere in the University remotely via national or international telecommunication networks. The performance of librarians also gets improved with the automation of serial service which is published at regular intervals and the publication is intended to continue indefinitely. The term serial control usually denotes two very distinct aspects: bibliographic control and processing control. Bibliographic control of serials involves preparation and maintenance of a central master list of all serial publications which includes full title, short title, variation form, earlier titles, publishers, ISSN, frequency etc. Serials processing control comprises of acquisition, claims controls, cataloguing, circulation, binding, weeding etc. (Vyasamoorthy, 2007).

\subsection{Conceptual Model}

Library Automation

Automated Acquisition
Automated Cataloguing
Automated Circulation
Automated Referencing
Automated Serials
Automated OPAC

Librarians' Performance

Figure. 1 Conceptual model for the study

The conceptual model in Figure 2.2 shows linkages and relationship among Automation of library, electronic resources use (independent variables) and librarians' performance (dependent variable). Automation of library in this context is related to daily activities of libraries which include acquisition processes of any materials in the library, the cataloguing of library materials, circulation process (checking in and checking out of library materials), serials control (these keep the frequency of journals) and the OPAC where library materials are visible to users. The automated services in the library helps library staff to process library materials without wasting time and enables them to meet up with the request from their patron. The automated services in the 
library will bring improvement in the quality of services rendered by the library.

\subsection{Methodology}

Survey research design was adopted for the study. This is to establish the relationship between the independent variable and the dependent variable. In this study, the independent variable is library automation (acquisition, cataloguing, circulation, reference and serials) while the dependent variable is librarians' performance in private universities in South-West Nigeria. The reason for this technique was the suitability for the variables involves with the sizeable number of population and due to the fact, that, the respondents of the research are not in the same particular location.

The target population for this study were libraries in private universities in South-West, Nigeria. There were twenty-two (22) private universities established between 1999 and 2014 in South-West, Nigeria, (National University Commission, 2015). From the statistics of the university libraries of each private university there were a total of 349 librarians in the 22 private universities in South-West, Nigeria. There were no sampling techniques used for this study since all the libraries in the 22 private universities in South-West, Nigeria were involved. The study used total enumeration sample size because this technique involves examining the entire population of the study.

349 copies of questionnaire were administered to librarians in 22 private universities in South -West, out of which 317 copies were returned and 272 were adequately filled. The result presented in this chapter is based on 272 copies of questionnaire that were accurately filled and returned. Descriptive Statistics and Inferential Statistics such as percentage distribution, mean and standard deviation were used to analyze the data collected. Regression analysis was used to determine the composite effect of library automation (independent variable) on librarians' performance (dependent variable). Pearson Product Moment Correlation Coefficient was used to test relationship between the variables at 0.05 levels of significance.

\subsection{Presentation and Analysis of Data}

Question 1: What is the level of library automation in private Universities in South-West, Nigeria? Table 1

\begin{tabular}{|c|l|l|l|l|}
\hline S/N & Automation of Library & $\begin{array}{l}\text { Fully } \\
\text { Automated }\end{array}$ & $\begin{array}{l}\text { Partially } \\
\text { Automated }\end{array}$ & $\begin{array}{l}\text { Not } \\
\text { Automated }\end{array}$ \\
\hline 1 & Acquisition & $128(47.1 \%)$ & $90(33.1 \%)$ & $54(19.9 \%)$ \\
\hline 2 & Cataloguing & $254(93.4 \%)$ & $18(6.6 \%)$ & - \\
\hline 3 & Circulation & $253(93.0 \%)$ & $19(7.0 \%)$ & - \\
\hline 4 & Serials & $218(80.1 \%)$ & $36(13.2 \%)$ & $18(6.6 \%)$ \\
\hline 5 & $\begin{array}{l}\text { Online Public Access Cataloguing } \\
\text { (OPAC) }\end{array}$ & $253(93.0 \%)$ & $19(7.0 \%)$ & - \\
\hline 6 & References & $145(53.3 \%)$ & $55(20.2 \%)$ & $72(26.5 \%)$ \\
\hline
\end{tabular}

The result in Table 1 displays the distribution of respondents on the level of Automation of library in private universities in South-West, Nigeria. Out of 6 automated library services identified in this study, 5 were fully automated, these include cataloguing (93.4\%), circulation (93.0\%), Online Public Access Cataloguing $(93.0 \%)$, Serials $(80.1 \%)$ and References $(53.3 \%)$. While only the Acquisition $(33.1 \%)$ was partially automated. This implies that there is high level of Automation of library in private universities. This finding is in agreement with the statement of Udding (2009) that library automation is now commonly used in libraries today. Neelakandan, Duraisekar, Balasubramani, and Ragavan (2010) added that application of modern techniques in the form of automation has become absolutely indispensable. 
Research Question : What are the Perceived effect of library automation on performance of librarians in private university in South-West, Nigeria

Table 2

\begin{tabular}{|c|c|c|c|c|c|}
\hline $\mathbf{S} / \mathbf{N}$ & Work Performance Measurement & $\begin{array}{l}\text { Strongly } \\
\text { Agree }\end{array}$ & Agree & Disagree & $\begin{array}{l}\text { Strongly } \\
\text { Disagree }\end{array}$ \\
\hline 1 & $\begin{array}{l}\text { Library automation has made the location and } \\
\text { description of library materials easier. }\end{array}$ & $182(66.9 \%)$ & $64(23.5 \%)$ & $26(9.6 \%)$ & - \\
\hline 2 & $\begin{array}{l}\text { Library automation has increased the quality of } \\
\text { my work }\end{array}$ & $181(66.5 \%)$ & $65(23.9 \%$ & $26(9.6 \%)$ & - \\
\hline 3 & $\begin{array}{l}\text { Library automation has increased the number of } \\
\text { library users. }\end{array}$ & $164(60.3 \%)$ & $82(30.1 \%)$ & $26(9.6 \%)$ & - \\
\hline 4 & $\begin{array}{l}\text { The implementation of Library automation has } \\
\text { made record and materials update easier. }\end{array}$ & $183(67.3 \%)$ & $46(16.9 \%)$ & $17(6.2 \%)$ & $26(9.6 \%)$ \\
\hline 5 & $\begin{array}{l}\text { Library automation has made use of library } \\
\text { more convenient }\end{array}$ & $182(66.9 \%)$ & $64(23.5 \%)$ & $26(9.6 \%)$ & - \\
\hline 6 & $\begin{array}{l}\text { Duplication of library records and materials has } \\
\text { been reduced since the implementation of } \\
\text { automation and electronic information } \\
\text { resources' use in the library. }\end{array}$ & $163(59.9 \%)$ & $66(24.3 \%)$ & - & $43(15.8 \%)$ \\
\hline 7 & $\begin{array}{l}\text { Library automation allows books or materials to } \\
\text { be reserved by library patrons. }\end{array}$ & $132(48.5 \%)$ & $114(41.9 \%)$ & $26(9.6 \%)$ & - \\
\hline 8 & $\begin{array}{l}\text { Library automation has increased the quantity } \\
\text { of work accomplished daily. }\end{array}$ & $131(48.2 \%)$ & $115(42.3 \%)$ & $26(9.6 \%)$ & - \\
\hline 9 & $\begin{array}{l}\text { Library automation has reduced the time spent } \\
\text { in classification and cataloguing processes. }\end{array}$ & $149(54.8 \%)$ & $65(23.9 \%)$ & $58(21.4 \%)$ & - \\
\hline 10 & $\begin{array}{l}\text { Library automation has increased my efficient } \\
\text { and effective use of resources. }\end{array}$ & $100(36.8 \%)$ & $131(48.2 \%)$ & $41(16.1 \%)$ & \\
\hline 11 & $\begin{array}{l}\text { Library automation has helped the library in } \\
\text { management of funds. }\end{array}$ & $99(36.4 \%)$ & $114(41.9 \%)$ & $59(17.7 \%)$ & - \\
\hline 12 & Automation has improved my service delivery. & $82(30.1 \%)$ & $147(34.0 \%)$ & $43(15.8 \%)$ & - \\
\hline 13 & $\begin{array}{l}\text { Library automation has allowed the library } \\
\text { users to make suggestion and contribution to } \\
\text { the growth of the library. }\end{array}$ & $83(30.6 \%)$ & $132(48.5 \%)$ & $57(21.0 \%)$ & - \\
\hline 14 & $\begin{array}{l}\text { Library automation has reduced my cost of } \\
\text { communication with other librarians and library } \\
\text { patron. }\end{array}$ & $99(36.4 \%)$ & $130(47.8 \%)$ & $26(9.6 \%)$ & - \\
\hline 15 & $\begin{array}{l}\text { Library automation has helped me to adhere to } \\
\text { library policy. }\end{array}$ & $115(42.3 \%)$ & $81(29.8 \%)$ & $59(22.7 \%)$ & $17(6.2 \%)$ \\
\hline 16 & $\begin{array}{l}\text { Library automation has reduced the time spent } \\
\text { on processing or retrieval of materials. }\end{array}$ & $99(36.4 \%)$ & $98(36.0 \%)$ & $42(25.5 \%)$ & $33(12.1 \%)$ \\
\hline
\end{tabular}

From the result in Table 2, it is obvious that library automation and electronic information resources' use are determinants of library performance. The result shows that more than $90.5 \%$ of the respondents claimed that library automation has increased quality of library work $(90.4 \%)$, made the location and description of library materials easier $(90.4 \%)$, increased number of library users $(90.4 \%)$, made record and materials update easier $(90.4 \%)$, reduced duplication of library records or materials $(84.2 \%)$, made it convenient for library users to use library $(90.4 \%)$, increased quantity of works accomplish daily $(90.4 \%)$, allowed books or materials to be reserved $(90.4 \%)$, increased the level of problem solving ability $(84.6 \%)$, increased efficient and effective use of resources available in the library $(85.0 \%)$ and reduced cost of communication with librarians and library patron $(84.2 \%)$. This finding is in agreement with the submission of Oyedun, (2007), that electronic information resources and automated library services are facilities that assist the library to offer quick, adequate and efficient services to their clientele. It also helps them to meet the diverse needs of their patrons.

Similarly, Bernroiders (2013), Osunrinde, Adekiya and Adeyemo (2009) also complement that electronic resources have many functions and benefits which can be of immense use to students in schools and educational sectors, particularly research institutions. Once the user is connected to the internet, the user can link up with any part of the world for whatever purpose the user intends. Sudhamani (2010) also supports that library automation improves the quality, speed and effectiveness of service and improves access to remote users. Aswal (2006) also corroborates that library automation is pivotal to library effectiveness because it increases staff productivity, enhances housekeeping operations, enables advancement in technology, and enables access to external 
information through the internet.

The result also shows that about $79 \%$ of the respondents are of the same opinion that library automation and resources reduced the time spent in classification and cataloguing $(79.1 \%)$, made work easier for them (71.7\%), helped the library in management of fund (78.3\%), improved library service delivery (64.1\%), allowed the library users to make suggestion and contribution to the growth of the library $(79.1 \%)$, helped librarians to adhere to library policy $(72.1 \%)$ and reduced the time spent on processing or retrieval of materials $(72.4 \%)$. This finding agrees with the submission of Fatoki (2002) that library automation helps to promote resource sharing by saving a lot of time and effort of library staff as well as the users. Neelakandan et al (2010) also substantiate that automated library helps its users with quick, accurate and prompt services. Automating the information available in the library benefits both the staff and users alike.

Research Question: What are the challenges of library automation in private universities in South-West, Nigeria?

Table 3

\begin{tabular}{|l|l|l|l|l|l|}
\hline S/N & $\begin{array}{l}\text { Challenges of Library Automation and } \\
\text { Electronic Resources }\end{array}$ & $\begin{array}{l}\text { Strongly } \\
\text { agree }\end{array}$ & Agree & Disagree & $\begin{array}{l}\text { Strongly } \\
\text { Disagree }\end{array}$ \\
\hline 1 & Electric power outage & $179(65.8 \%)$ & $34(12.5 \%)$ & $42(15.5 \%)$ & $17(6.2 \%)$ \\
\hline 2 & Internet fluctuation & $178(65.8 \%)$ & $34(12.5 \%)$ & $43(15.8 \%)$ & $17(6.2 \%)$ \\
\hline 3 & Computer system problem & $114(41.9 \%)$ & $81(29.8 \%)$ & $34(12.5 \%)$ & $43(15.8 \%)$ \\
\hline 4 & Staff training deficiency & $97(35.7 \%)$ & $115(42.3 \%)$ & $43(15.8 \%)$ & $17(6.2 \%)$ \\
\hline 5 & Lack of infrastructure & $96(35.3 \%)$ & $83(30.5 \%)$ & $50(18.4 \%)$ & $43(15.8 \%)$ \\
\hline 6 & Software compatibility problems & $65(23.9 \%)$ & $130(47.8 \%)$ & $51(18.8 \%)$ & $26(9.6 \%)$ \\
\hline 7 & Computer illiteracy & $48(17.6 \%)$ & $131(48.2 \%)$ & $33(12.1 \%)$ & $60(22.1 \%)$ \\
\hline 8 & Lack of support from librarians & $51(18.8 \%)$ & $97(35.7 \%)$ & $66(24.3 \%)$ & $58(21.4 \%)$ \\
\hline 9 & Lack of technical support from vendor & $16(5.9 \%)$ & $165(60.7 \%)$ & $31(11.4 \%)$ & $34(12.5 \%)$ \\
\hline
\end{tabular}

\section{Source: Field survey, 2016}

The result in Table 3 shows the opinion of the respondents on the challenges of library automation in private universities South-West, Nigeria. From the result, electric power outage (78.3\%), internet fluctuation $(78.3 \%)$, virus $(77.9 \%)$, computer system problem $(71.7 \%)$, staff training deficiency $(78.0 \%)$, software compatibility $(71.7 \%)$, and lack of infrastructure $(65.8 \%)$ are the major challenges librarians face in automating library services and electronic information resources in Nigerian private universities. This finding is in agreement with the study of Raiz (2008) who in his study found fear of adverse impact on employment, technology cost, library staff extensive training, lack of support from the management, budget constraints and retrospective conversion of data as barriers faced by the library during automation.

\subsection{Test of Hypothesis}

HO $_{1}$ : There is no significant relationship between library automation and performance of librarians in private universities in South West, Nigeria.

The Pearson Product Moment Correlation was carried out to ascertain if there is relationship between library automation and librarians' performance in private universities in South West, Nigeria. The result is presented in Table 4.7 .

Table4: Correlation Analysis of Library Automation and Librarians' Performance in Private Universities in South -West, Nigeria ( $\mathbf{N}=\mathbf{2 7 2}$ )

\begin{tabular}{|l|l|l|l|l|l|}
\hline Variables & Mean & Std. Dev & R & p.value & Remark \\
\hline Library automation & 8.0000 & 1.89581 & $.372^{* *}$ & .000 & Sig. \\
\hline Library Performance & 88.4431 & 7.37970 & & & \\
\hline
\end{tabular}

**correlation is significant at 0.01 .

The result in Table 4 shows that there was significant and positive relationship between library automation and performance librarians in private universities $(\mathrm{r}=.372, \mathrm{P}(.000)<.01)$. The implication of this result is that, if library automation is instigated it will positively influence librarians' performance. This finding of the research study corroborates those of Balogun, Oladipo and Odekunle (2010) who discovered that high performance is dependent on the level of good environment of the work force and library automation. Vyasamoorthy (2007) also supports that, the performance of librarians gets improved with the automation of serial service which is published at regular intervals and the publication is intended to continue indefinitely. Therefore, the hypothesis $\left(\mathrm{HO}_{1}\right)$ that, there is no significant relationship between library automation and librarians' performance was rejected in favour of the alternative.

\subsection{Summary}

This study was aimed at finding out if library automation were correlates of librarians' performance in private 
universities in South-West, Nigeria.

From the result of the study, there was high level of library automation in private universities. Among many factors, the study deduced electricity power outage, internet fluctuation, virus, lack of frequent subscription, computer system problem, staff training deficiency, limited space, software compatibility, nature and types of eresources subscribed to, lack of commitment by staff and lack of infrastructure as the major challenges of library automation in Nigerian private universities. There was significant and positive relationship between library automation and librarians' performance in Nigerian private universities. Lastly, library automation has significant influenced librarians' performance in Nigerian private universities.

\subsection{Conclusion}

Library automation had positive and significant influence on librarians' performance in private universities. The use of electronic information resources had negative influence on librarians' performance. The study revealed that library automation and electronic information resources use are determinant factors of librarians' performance in private universities in South-West, Nigeria.

\subsection{Recommendations}

Based on the findings of the study the following recommendations are made: Having discovered the importance of library automation on librarians' performance, and the result of the finding revealed that acquisition service 90 $(33.1 \%)$ was partially automated there is need for university library management and librarians to ensure that the acquisition service should be fully automated due to the fact that it will help the library to manage fund given to them properly. The University management, Library Department in particular, should ensure stable electricity supply by providing standby generators which serve as alternative source of power supply and at the same time offer support for users on the use of available e-resources in order to encourage the users.

\section{References}

Alabi. O and Inuwa, B. (2010). Effect of the on -line Public Access Catalogue (OPAC) on the academic performance of Undergraduate Students in Nigeria: The experience at the University of Lagos and American University of Nigeria. Proceeding of the Professional Summit on Information Science and Technology held at UN N May 3rd -7th, 116-122.

Aswal, R. S. (2006). Library Automation for 21st Century. New Delhi: ESS ESS Publications. Pp5-8

Balogun, S, Oladipo S \& Odekunle, S (2010). Influence Of Job Esteem And Job Status On Organizational Commitment Of Employees Of Selected B anks In Nigeria. Academic Leadership: The Online Journal Vol 8 , Issue 2 pp 1-10

Bernroider, E., Pilkington, A. and José-Rodrigo C. (2013). Research in information systems: a study of diversity and inter-disciplinary discourse in the AIS basket journals between 2005 and 2011. Journal of Information Technology 28, 74-89 (December 2015)

Borman, W. C., \& Motowidlo, S. J. (2012). Expanding the criterion domain to include elements of contextual performance. In N. Schmitt \& W. Borman (Eds.), Personnel selection in organizations (pp. 71-98). New York: Jossey-Bass.

Bradford, D.L. \& Burke, W.W. eds, (2005). Organization Development. San Francisco: Pfeiffer Newton Margulies. (1972).Organizational Development Theory".http://www.med. upenn.edu/hbhe4part4-ch15organizational-development-theory.shtmlRetrieved 2016-05-20.

Fatoki O.C (2004). Library Automation in Nigeria; the Kenneth Dike Library experience. Lagos Journal of Library Information Science 2 (2) 111-116

Fatoki, O. C. (2004), Impact of library resources and Internet on undergraduate Students' research: University of Ibadan, Nigeria. Nigerian Libraries, 38(1):21-33

Gbadamosi, Belau Olatunde (2011). Assessing Library Automation and Virtual Library Development in Four Academic Libraries in Oyo, Oyo State, Nigeria. US-China Education Review, 8 (5):711-717

Hussain, A., \& Raza, M. M. (2002). Online Public Access Catalogue: IASLIC Bulletin, 205. Indira Gandhi Institute of Development Research, Delhi http:// www.igidr.ac.in/lib/paperlhtm access on 05/09/2015.

Moore, N. (2003). Measuring the performance of public libraries. IFLA Journal, 15, 18-22. Morris, A., Hawkins, M., \& Sumsion, J. (2001). The economic value of public libraries. London: Resource

Moorthy, A. (2004). Library Automation in India. In Horizon of Information Technology: New Age, New Wage Trend and Impact of Library Science." A Festschcrift" 5 (1):78-99 on the occasion of 55th birth anniversary of Dr. R.P.Kumar. Pane: Inamdar Bandhu Prakashan.

Motowidlo, S. J. (2003). "Job Performance”, in W.C. Borman, D.R. Ilgen, and R.J. Klimoski (Eds.). Handbook of Psychology: 12 Industrial and Organizational Psychology. Hoboken, NJ: John Wiley and Sons.

Neelakandan.B, Duraisekar. S, Balasubramani.R, \& Srinivasa Ragavan. S (2010). Implementation of Automated Library Management System in the School of Chemistry Bharathidasan University using Koha Open 
Source Software. International Journal of Applied Engineering Research,1(1)Available: http://www.ipublishing.co.in/jarvol1no12010/EIJAER1014.pdf.

Osunrinde, A. A., Adekiya, I. A. \& Adeyemo, K. A. (2002 ). Self-Efficacy and Use of Electronic Information as Predictors of Academic Performance. A Journal of Library and Information Science Vol. 7, No. 1, JanuaryMarch 2013: 50-56

Oyedun, $G$ (2007). Internet use in the library of federal University of Technology Minna Gateway Library Journal. Vol, 10:No. 1 Pp. 23-26.

Oyintola I.A, Abiodun O.I \& Ajani F.O (2013). Work environments and job performance of library in the public universities in South -west Nigeria. International Journal of Library and Information Science. Vol. 5(11), pp. 457-461

Satyanarayana, N. R. (2013). A Manual of Library Automation and Networking. Lucknow: New Royal Book co. 148.

Sudhamani, K. S. (2010). Assessment and Evaluation of Open Source Library Automation Software KOHA and NewGenLib Adaptable to RGUHS Digital Library Operations and Functions. Being a report submitted to the Rajiv Gandhi University of Health Sciences in partial fulfillment of the requirement for the degree of a Postgraduate Diploma in Health Science Librarianship. Available:http://119.82.96.198:8080/jspui/bitstream/123456789/237/1/KOHA\%20and\%20Newgenlib.pdf.( September 10, 2016)

Uddin, H. (2009). Library Automaton: A study of the AIC, INSDOC and National Libraries of Bangaladesh. United Nation Educational Scientific and Cultural Organization, Paris http://www.unesco.org/webworld/index.5htm accessed on 30/09/2015

Yaya J. A. (2007). Job motivation and emotional intelligence as correlates of librarians' performance in selected university libraries in South West, Nigeria. Unpublished MLIS dissertation submitted to the department of Library and Information Studies (LARIS), University of Ibadan, Oyo State. 